\title{
Pengembangan Bahan Ajar Interaktif Berbasis Pendekatan Kontekstual Pada Materi Persamaan Garis Lurus Kelas VIII Sekolah Menengah Pertama
}

\author{
Nina Wardatunnisa, Ratnaningsih, dan Sri Sudaryati \\ Universitas Negeri Jakarta \\ Gedung Rd. Dewi Sartika, Kampus A UNJ \\ Jalan Rawamangun Muka, Jakarta Timur, 13220 \\ Telp./Faksimile (+62-21) 29266006 / (+62 21) 4898486 \\ reunina@live.com
}

\begin{abstract}
Abstrak
Penelitian ini bertujuan untuk mengembangkan bahan ajar interaktif berbasis pendekatan kontekstual pada materi persamaan garis lurus kelas VIII Sekolah Menengah Pertama. Berdasarkan analisis kebutuhan, materi dalam bahan ajar yang dikembangkan adalah persamaan garis lurus menggunakan pendekatan kontekstual. Pendekatan kontekstual terdiri atas tujuh asas yaitu, konstruktivisme (constructivism), inkuiri (inquiry), bertanya (questioning), masyarakat belajar (learning community), memodelan (modelling), refleksi (reflection), dan penilaian nyata (authentic assesment). Ketujuh asas tersebut terdapat pada bagian-bagian di dalam bahan ajar.

Metode yang digunakan pada penelitian ini adalah penelitian dan pengembangan (research and development). Prosedur penelitian dan pengembangan ini terdiri dari enam tahap, yaitu analisis kebutuhan, pengembangan produk awal, validasi ahli dan revisi, uji coba perorangan dan revisi, uji coba lapangan skala kecil dan revisi, dan uji coba skala besar dan produk akhir.

Berdasarkan hasil validasi ahli materi dan bahasa, diperoleh persentase sebesar $89,40 \%$ dengan kategori sangat baik. Bahan ajar yang dikembangkan sesuai dengan kurikulum yang berlaku dan bahan ajar sesuai dengan asas pendekatan kontekstual. Berdasarkan hasil validasi ahli media, diperoleh persentase $82,90 \%$ dengan kategori sangat baik. Bahan ajar yang dikembangkan interaktif dan memunculkan motivasi untuk belajar. Berdasarkan hasil uji coba perorangan, diperoleh persentase sebesar 84,70\% dengan kategori sangat baik. Persentase yang diperoleh dari uji coba lapangan skala kecil yaitu 88,30\% dengan kategori sangat baik. Begitu juga dengan uji coba skala besar, diperoleh kategori sangat baik dengan persentase sebesar 90,50\%. Berdasarkan hasil uji coba tersebut, dapat dikatakan bahwa bahan ajar matematika yang dikembangkan memenuhi kelayakan untuk digunakan pada pembelajaran materi persamaan garis lurus kelas VIII Sekolah Menengah Pertama.
\end{abstract}

Kata kunci: Bahan Ajar, Interaktif, Kelas VIII SMP, Research and Development, Pendekatan Kontekstual, Persamaan Garis Lurus

\section{Pendahuluan}

\section{A. Latar Belakang Masalah}

Sumber Daya Manusia (SDM) yang berkualitas merupakan salah satu komponen penting untuk meningkatkan kualitas suatu bangsa. Peningkatan kualitas SDM dapat ditempuh melalui pendidikan, baik pendidikan formal, nonformal, maupun informal. Sekolah Menengah Pertama (SMP) merupakan salah satu jenjang dalam pendidikan formal yang menjadi sarana strategis untuk menciptakan SDM yang berkualitas melalui proses pembelajaran.

Matematika merupakan mata pelajaran yang terdapat pada setiap jenjang pendidikan. Saat ini masih ada siswa yang menganggap bahwa matematika merupakan pelajaran yang sulit. Oleh karena itu, dilakukan penelitian pendahuluan untuk analisis kebutuhan siswa. Penelitian pendahuluan dilakukan di SMP Negeri 30 Jakarta dengan menyebar kuesioner pada 52 siswa serta melakukan wawancara pada dua orang guru matematika di sekolah tersebut. Berdasarkan penelitian pendahuluan yang dilakukan, dapat diketahui bahwa terdapat beberapa faktor yang menyebabkan materi matematika sulit dipahami siswa. Faktor-faktor yang menyebabkan materi matematika sulit dipahami siswa di antaranya yaitu cara penyajian kurang menarik (51,92\%), terlalu abstrak (28,85\%), dan tidak bisa dikaitkan dengan kehidupan sehari-hari $(13,46 \%)$. 
Persamaan garis lurus merupakan salah satu materi yang terdapat dalam pelajaran matematika kelas VIII semester ganjil. Sebanyak 59,62\% dari total 52 siswa SMP Negeri 30 Jakarta menyatakan bahwa materi yang paling sulit dipahami adalah persamaan garis lurus. Kedua guru pun menyatakan bahwa materi paling sulit dipahami siswa yaitu persamaan garis lurus.

Berbasis pada analisis kebutuhan siswa dan hasil wawancara guru, dapat dikatakan bahwa diperlukan adanya pengembangan bahan ajar interaktif berbasis pendekatan kontekstual pada materi persamaan garis lurus kelas VIII SMP.

\section{B. Fokus Masalah}

Fokus masalah dalam penelitian ini adalah diperlukan adanya pengembangan bahan ajar interaktif berbasis pendekatan kontekstual pada materi persamaan garis lurus kelas VIII Sekolah Menengah Pertama sebagai salah satu alternatif solusi pembelajaran persamaan garis lurus.

\section{Perumusan Masalah}

Fokus masalah dijabarkan menjadi rumusan masalah yang dijawab pada hasil penelitian.

1. Bagaimana mengembangkan bahan ajar interaktif berbasis pendekatan kontekstual pada materi persamaan garis lurus kelas VIII SMP?

2. Bagaimana kelayakan bahan ajar interaktif berbasis pendekatan kontekstual pada materi persamaan garis lurus kelas VIII SMP?

D. Kegunaan Hasil Penelitian

1. Bagi siswa, khususnya siswa SMP Negeri 30 Jakarta, produk akhir penelitian ini bermanfaat untuk menjadikan kegiatan belajar persamaan garis lurus menjadi lebih menarik dan bermakna.

2. Bagi guru, khususnya guru SMP Negeri 30 Jakarta, produk akhir penelitian ini dapat dijadikan alternatif pembelajaran.

3. Bagi sekolah, khususnya SMP Negeri 30 Jakarta, produk akhir penelitian ini dapat dijadikan sebagai salah satu alternatif bahan ajar yang dapat mendukung kegiatan belajar mengajar persamaan garis lurus di sekolah.

II. Isi

A. Deskripsi Teori

1. Bahan Ajar Interaktif

Menurut National Center for Vocational Education Research Ltd/National Center for Competency Based Training, yang dikutip oleh Majid, bahan ajar adalah segala bentuk bahan yang digunakan untuk membantu guru/instruktur dalam melaksanakan kegiatan belajar mengajar di kelas. ${ }^{1}$ Menurut Majid, bahan ajar adalah seperangkat materi yang disusun secara sistematis sehingga tercipta lingkungan/suasana yang memungkinkan siswa belajar dengan baik. ${ }^{2}$ Menurut Maryani, interaktif berarti bersifat saling mempengaruhi, yaitu terdapat hubungan timbal balik antara pengguna dan media. ${ }^{3}$ Menurut Prastowo, bahan ajar interaktif adalah bahan ajar yang mengombinasikan beberapa media pembelajaran (audio, video, teks, atau grafik) yang bersifat interaktif untuk perintah atau perilaku alami dari suatu presentasi. ${ }^{4}$

\section{Pendekatan Kontekstual (Contextual Teaching and Learning)}

Menurut Hanafiah dan Suhana, pendekatan kontekstual merupakan suatu proses pembelajaran holistik yang bertujuan untuk membelajarkan siswa dalam memahami bahan ajar

1 Abdul Majid, Perencanaan Pembelajaran; Mengembangkan Standar Kompetensi Guru, (Bandung: PT Remaja Rosdakarya, 2005), h.174.

2 Ibid.

3 Sri Maryani, "Pengembangan Bahan Ajar Berbasis Multimedia Interaktif Mata Kuliah Komputasi Akuntansi” (Artikel, Universitas Gunadarma, 2009).

4 Andi Prastowo, Panduan Kreatif Membuat Bahan Ajar Inovatif (Jogjakarta: DIVA Press, 2011), h.330. 
secara bermakna (meaningful) yang dikaitkan dengan konteks kehidupan nyata, baik berkaitan dengan lingkungan pribadi, agama, sosial, ekonomi, maupun kultural. ${ }^{5}$

Sanjaya menyatakan bahwa CTL sebagai suatu pendekatan pembelajaran memiliki 7 asas. $^{6}$ Ketujuh asas tersebut adalah konstruktivisme (constructivism), inkuiri (inquiry), bertanya (questioning), masyarakat belajar (learning community), pemodelan (modeling), refleksi (reflection), dan penilaian nyata (authentic assesment).

\section{Persamaan Garis Lurus}

Agus menyatakan bahwa persamaan garis lurus adalah suatu persamaan yang jika digambarkan ke dalam bidang koordinat Cartesius akan membentuk sebuah garis lurus. ${ }^{7}$

a. Bentuk dan grafik persamaan garis lurus

Bentuk persamaan garis lurus yaitu $y=m x+c$ atau $a x+b y+c=0$. Untuk menggambar grafik persamaan garis lurus pada bidang Cartesius, dapat digunakan tabel pasangan berurutan.

b. Gradien persamaan garis lurus $(m)$

Gradien adalah kemiringan/kecondongan suatu garis, yang merupakan koefisien dari $x{ }^{8}$ Gradien dilambangkan dengan $m$. Ukuran gradien dapat ditentukan dengan membandingkan perubahan nilai $y$ dan perubahan nilai $x$.

c. Menentukan persamaan garis lurus

Persamaan garis lurus yang melalui dua titik $P\left(x_{1}, y_{1}\right)$ dan $Q\left(x_{2}, y_{2}\right)$ adalah

$\frac{y-y_{1}}{y_{2}-y_{1}}=\frac{x-x_{1}}{x_{2}-x_{1}}$. Sedangkan persamaan garis lurus yang melalui satu titik dengan gradien $m$ adalah $P(a, b)$ adalah $y-b=m(x-a)$.

\section{B. Kerangka Berpikir}

Guru membutuhkan seperangkat materi yang disusun secara sistematis untuk disampaikan kepada siswa, yaitu bahan ajar. Berdasarkan analisis kebutuhan yang dilakukan di SMP Negeri 30 Jakarta, materi yang paling dianggap sulit oleh siswa adalah persamaan garis lurus. Faktor-faktor yang menyebabkan sulitnya siswa dalam memahami materi matematika adalah cara penyajian kurang menarik, materi terlalu abstrak, serta materi tidak bisa dikaitkan dengan kehidupan seharihari. Agar lebih bermakna, pendekatan yang dapat dijadikan salah satu alternatif adalah pendekatan kontekstual. Berdasarkan uraian yang telah dipaparkan, dalam penelitian ini akan dikembangkan produk bahan ajar interaktif dengan pendekatan kontekstual.

\section{Rancangan Model}

Produk yang akan dihasilkan adalah sebuah bahan ajar interaktif pada materi persamaan garis lurus kelas VIII SMP berbasis pendekatan kontekstual. Pada halaman awal terdapat intro yang mengarah pada beranda. Dalam menu utama terdapat tombol-tombol utama, yaitu tombol Pengertian Persamaan Garis Lurus, Gradien, Menentukan Persamaan Garis Lurus, dan Evaluasi. Selain itu terdapat tombol-tombol lain seperti tombol Beranda, Kompetensi, Bantuan, Suara, dan Keluar.

\section{Metodologi Penelitian}

A. Tujuan Penelitian

5 Nanang Hanafiah dan Cucu Suhana. Konsep Strategi Pembelajaran (Bandung: PT Refika Aditama, 2009), h.67.

6 Wina Sanjaya, Strategi Pembelajaran Berorientasi Standar Proses Pendidikan (Jakarta: Kencana, 2010), h.264.

7 Nuniek Avianti Agus. Mudah Belajar Matematika (Jakarta: Pusat Perbukuan Departemen Pendidikan Nasional, 2008), h.41.

8 Sri Maemanah, Pelajaran Matematika; Untuk SMP/MTs Kelas VIII (Depok: Arya Duta, 2007), h. 56. 
Penelitian ini bertujuan untuk mengetahui bagaimana mengembangkan bahan ajar interaktif berbasis pendekatan kontekstual pada materi persamaan garis lurus kelas VIII Sekolah Menengah Pertama (SMP) dan mengetahui kelayakan bahan ajar tersebut.

\section{B. Tempat dan Waktu Penelitian}

Penelitian pendahuluan dan uji coba bahan ajar ini dilaksanakan di SMP Negeri 30 Jakarta. Penelitian pendahuluan dilakukan pada semester genap tahun pelajaran 2013/2014. Uji coba bahan ajar dilakukan pada semester genap tahun pelajaran 2015/2016.

\section{Metode Penelitian}

Metode yang digunakan dalam penelitian ini adalah metode penelitian dan pengembangan. Sugiyono mendefinisikan, metode penelitian dan pengembangan atau dalam bahasa Inggris Research and Development (R\&D) adalah metode penelitian yang digunakan untuk menghasilkan produk tertentu dan menguji keefektifan produk tersebut. ${ }^{9}$

\section{Prosedur Penelitian Pengembangan Model}

Tim Puslitjaknov mengemukakan lima langkah utama prosedur penelitian pengembangan menurut Borg dan Gall. Kelima langkah tersebut adalah sebagai berikut.

1. Melakukan analisis produk yang akan dikembangkan

2. Mengembangkan produk awal

3. Validasi ahli dan revisi

4. Uji coba lapangan skala kecil dan revisi produk

5. Uji coba lapangan skala besar dan produk akhir. ${ }^{10}$

Berbeda dengan yang dikemukakan oleh Borg dan Gall, langkah-langkah utama dari model desain pembelajaran menurut Dick dkk., yang dikutip oleh Pribadi, terdiri atas:

1. Mengidentifikasi tujuan pembelajaran

2. Melakukan analisis instruksional

3. Menganalisis karakteristik siswa dan konteks pembelajaran

4. Merumuskan tujuan pembelajaran khusus

5. Mengembangkan istrumen penilaian

6. Mengembangkan strategi pembelajaran

7. Mengembangkan dan memilih bahan ajar

8. Merancang dan mengembangkan evaluasi formatif

9. Melakukan revisi terhadap program pembelajaran

10. Merancang dan mengembangkan evaluasi sumatif. ${ }^{11}$

Langkah-langkah awal penelitian pengembangan ini mengacu pada prosedur penelitian pengembangan menurut Borg dan Gall. Namun, setelah langkah ketiga menurut Borg dan Gall, yaitu validasi ahli dan revisi, langkah yang digunakan adalah langkah kedelapan menurut Dick dan Carey, yaitu merancang dan mengembangkan evaluasi formatif. Pribadi mengemukakan tiga jenis evaluasi formatif yang dapat diaplikasikan untuk mengembangkan produk atau program pembelajaran dari model desain pembelajaran Dick dan Carey, yaitu evaluasi perorangan (one to one evaluation), evaluasi kelompok sedang (small group evaluation), dan evaluasi lapangan (field trial). ${ }^{12}$ Tahap evaluasi kelompok sedang menurut Dick dan Carey sama sama dengan uji coba lapangan skala kecil menurut Borg dan Gall. Selain itu, tahap evaluasi lapangan menurut Dick dan Carey sama dengan uji coba lapangan skala besar menurut Borg dan Gall. Dapat dikatakan bahwa langkah yang digunakan dalam penelitian ini merupakan langkah yang dikemukakan Borg dan

9 Sugiyono, Metode Penelitian Kuantitatif Kualitatif dan R\&D (Bandung: Alfabeta, 2009), h.297.

10 Tim Puslitjaknov, Metode Penelitian dan Pengembangan (Jakarta: Pusat Penelitian Kebijakan dan Inovasi Pendidikan Badan Penelitian dan Pengembangan Departemen Pendidikan Nasional, 2008), h.11.

11 Benny A. Pribadi, Model Desain Sistem Pembelajaran (Jakarta: Dian Rakyat, 2009), h.99.

12 Ibid. 
Gall dengan penambahan langkah sesudah validasi ahli dan revisi, yaitu uji coba atau evaluasi perorangan.

\section{Penelitian Pendahuluan}

Langkah awal dalam melakukan penelitian pengembangan ini adalah melakukan penelitian pendahuluan yang berupa analisis kebutuhan siswa dan guru. Instrumen yang digunakan berupa kuesioner. Langkah awal dalam melakukan analisis kebutuhan siswa yaitu membuat kisi-kisi kuesioner dan kuesioner analisis kebutuhan siswa. Total responden adalah 52 siswa. Data yang didapat berdasarkan penyebaran kuesioner kemudian dianalisis. Untuk analisis kebutuhan guru, instrumen yang digunakan berupa wawancara. Langkah awal dalam melakukan analisis kebutuhan guru yaitu membuat kisi-kisi. Kemudian dilanjutkan dengan membuat instrumen wawancara. Wawancara dilakukan kepada guru matematika SMP Negeri 30 Jakarta sebagai responden.

\section{Perencanaan Pengembangan Model}

Produk yang akan dikembangkan dalam penelitian ini adalah bahan ajar interaktif berbasis pendekatan kontekstual pada materi persamaan garis lurus kelas VIII SMP. Langkah awal dalam membuat desain awal produk adalah membuat diagram alir tampilan bahan ajar. Langkah selanjutnya adalah membuat Garis Besar Isi Media (GBIM) yang disesuaikan dengan KTSP. Setelah membuat GBIM, pembuatan jabaran materi persamaan garis lurus dilakukan. Jabaran materi tersebut dituangkan ke dalam story board. Story board yang telah dibuat diimplementasikan ke dalam bahan ajar interaktif dengan bantuan programmer yang akan menjadi produk awal penelitian.

\section{Validasi, Evaluasi, dan Revisi Model}

a. Validasi Ahli

Setelah produk awal dihasilkan, produk dicermati oleh para ahli, yaitu ahli materi dan bahasa dan ahli media untuk diberikan masukan. Ahli materi dan bahasa berjumlah 2 orang. Ahli media berjumlah 2 orang. Uji coba kepada para ahli dilakukan dengan memberikan produk awal, kemudian dicermati oleh masing-masing ahli. Setelah produk awal divalidasi dan dievaluasi oleh para ahli, produk direvisi. Revisi produk dilakukan berdasarkan kuesioner dan masukan para ahli tersebut.

\section{b. Uji Coba Perorangan}

Responden dalam uji coba perorangan terdiri dari 3 orang siswa SMP Negeri 30 Jakarta yang sedang atau telah mempelajari materi persamaan garis lurus. Siswa yang dijadikan responden uji coba perorangan adalah 1 siswa berkemampuan tinggi, 1 siswa berkemampuan sedang, dan 1 siswa berkemampuan rendah dalam mata pelajaran matematika.

\section{c. Uji Coba Lapangan Skala Kecil}

Responden dalam uji coba lapangan skala kecil lebih heterogen dan lebih banyak dibandingkan dengan uji coba perorangan. Siswa yang dijadikan responden yaitu 10 siswa SMP Negeri 30 Jakarta yang sedang atau telah mempelajari materi persamaan garis lurus.

\section{d. Uji Coba Lapangan Skala Besar}

Uji coba dalam tahap ini merupakan uji coba akhir dalam penelitian. Uji coba dilakukan dalam skala yang lebih besar dengan responden yang lebih banyak dan heterogen. Responden dalam uji coba lapangan ini terdiri dari 50 orang siswa SMP Negeri 30 Jakarta yang sedang atau telah mempelajari materi persamaan garis lurus.

\section{E. Teknik Pengumpulan Data dan Analisis Data \\ 1. Teknik Pengumpulan Data \\ a. Validasi Ahli}

Sumber data berasal dari kuesioner para ahli, yaitu ahli materi dan bahasa dan ahli media. Data yang digunakan dalam penelitian ini adalah data hasil validasi ahli materi dan bahasa serta 
ahli media. Responden diberikan produk awal, kemudian diminta untuk mencermati produk tersebut.

\section{b. Uji Lapangan}

Data yang digunakan dalam penelitian ini berupa data hasil uji coba produk yang diujikan kepada responden uji coba perorangan, uji coba skala kecil, dan uji coba skala besar. Data diperoleh menggunakan kuesioner.

\section{Teknik Analisis Data}

Hasil kuesioner dianalisis berdasarkan skala Likert berikut.

Tabel 1. Skala Penilaian Instrumen Penelitian ${ }^{13}$

\begin{tabular}{|c|l|c|c|c|}
\hline \multirow{2}{*}{ No. } & \multirow{2}{*}{ Pilihan Jawaban } & \multirow{2}{*}{ Kode } & \multicolumn{2}{|c|}{ Bobot Skor } \\
\cline { 4 - 5 } & & & Pernyataan Positif & Pernyataan Negatif \\
\hline 1. & Sangat setuju & SS & 5 & 1 \\
\hline 2. & Setuju & S & 4 & 2 \\
\hline 3. & Ragu-ragu & R & 3 & 3 \\
\hline 4. & Tidak setuju & TS & 2 & 4 \\
\hline 5. & Sangat tidak setuju & STS & 1 & 5 \\
\hline
\end{tabular}

Data yang diperoleh diinterpretasikan skornya seperti pada tabel di bawah ini. Skor yang dihasilkan merupakan bahan acuan dalam menentukan kelayakan produk yang dihasilkan. Produk dikatakan baik jika persentase minimal $61 \%$.

Tabel 2. Interpretasi Skor Instrumen Penelitian ${ }^{14}$

\begin{tabular}{|c|c|}
\hline Persentase & Interpretasi \\
\hline $0 \%-20 \%$ & Sangat Kurang \\
\hline $21 \%-40 \%$ & Kurang \\
\hline $41 \%-60 \%$ & Cukup \\
\hline $61 \%-80 \%$ & Baik \\
\hline $81 \%-100 \%$ & Sangat Baik \\
\hline
\end{tabular}

\section{Hasil Penelitian dan Pembahasan}

A. Pengembangan Model

\section{Hasil Analisis Kebutuhan}

Analisis kebutuhan dilakukan di SMP Negeri 30 Jakarta dengan menyebarkan kuesioner kepada 52 siswa dan mewawancarai dua orang guru matematika. Berdasarkan analisis kebutuhan yang dilakukan, dapat diketahui bahwa materi matematika yang dianggap paling sulit dipahami siswa adalah Persamaan Garis Lurus kelas VIII. Faktor-faktor yang menyebabkan materi matematika sulit dipahami siswa yaitu cara penyajian kurang menarik $(51,92 \%)$, terlalu abstrak (28,85\%), dan tidak bisa dikaitkan dengan kehidupan sehari-hari (13,46\%). Oleh karena itu diperlukan adanya suatu pendekatan pembelajaran yang mengaitkan antara materi persamaan garis lurus dengan konteks kehidupan sehari-hari agar pembelajaran menjadi lebih menarik dan bermakna. Pendekatan yang sesuai dengan kebutuhan tersebut adalah pendekatan kontekstual.

Bahan ajar yang dikembangkan berupa bahan ajar interaktif. Hal tersebut ditentukan berdasarkan hasil analisis kebutuhan yang dilakukan dengan menyebarkan kuesioner kepada siswa kelas XI SMP Negeri 30 Jakarta. Dari sebanyak 52 siswa yang dijadikan responden, 32,69\% siswa memilih CD interaktif sebagai bahan ajar yang paling dibutuhkan, 28,85\% siswa memilih modul, dan $21,15 \%$ siswa memilih LKS. Menurut hasil wawancara, guru berpendapat bahwa untuk materi-materi yang di dalamnya membahas grafik, penjelasan dengan bahan ajar atau metode yang dapat memperlihatkan langkah-langkah pembuatan grafik akan lebih efektif karena siswa akan lebih memahami proses-prosesnya.

13 Riduwan, Belajar Mudah Penelitian untuk Guru - Karyawan dan Peneliti Pemula (Bandung: Alfabeta, 2007), h.87.

14 Ibid., h.89. 


\section{Model Draft 1}

Bahan ajar interaktif ini dibuat menggunakan Adobe Flash Proffesional CS6 Script 2.0 dengan bantuan programmer. Dalam bahan ajar ini terdapat menu utama yang berisi tombol Persamaan Garis Lurus, Gradien, Menentukan Persamaan Garis Lurus, dan Evaluasi. Selain itu terdapat tombol lain seperti tombol Keluar. Selain itu terdapat materi, refleksi, dan evaluasi.

\section{Model Draft II}

\section{a. Hasil Validasi Ahli Materi dan Bahasa}

Model draft II merupakan hasil revisi dari model draft I berdasarkan saran dari kedua ahli materi dan bahasa. Model draft I diberikan kepada ahli materi dan bahasa untuk dilihat, dicermati, dan dikoreksi apabila ada kekurangan pada konsep materi maupun bahasa. Berdasarkan hasil validasi diperoleh saran untuk revisi, yaitu ukuran huruf diperbesar dan jenis huruf diganti agar dapat dibaca dengan jelas. Penulisan variabel harus miring dan menggunakan huruf khusus. Konteks telepon pada sub materi 1 diubah menjadi konteks volume bensin. Soal yang berupa soal cerita sebaiknya disertai ilustrasi berupa animasi agar lebih menarik dan mudah dipahami.

Aspek materi secara keseluruhan diperoleh persentase rata-rata sebesar $89,40 \%$. Jika ditinjau dari aspek materi maka bahan ajar yang dikembangkan termasuk kategori sangat baik. Aspek bahasa secara keseluruhan diperoleh persentase rata-rata sebesar 90,00\%. Jika ditinjau dari aspek bahasa maka bahan ajar yang dikembangkan termasuk kategori sangat baik. Persentase ratarata secara keseluruhan dari aspek materi maupun dari aspek bahasa diperoleh nilai sebesar $89,70 \%$. Dapat dikatakan bahwa bahan ajar yang dikembangkan baik secara keseluruhan maupun aspek materi dan bahasa diperoleh kategori sangat baik.

\section{b. Hasil Validasi Ahli Media}

Model draft II merupakan hasil revisi dari model draft I berdasarkan saran dan masukan dari dua orang ahli media. Model draft I diberikan kepada ahli media untuk dilihat, dicermati, dan dikoreksi apabila ada kesalahan serta kekurangan pada aspek tampilan, suara, maupun navigasi. Berdasarkan hasil validasi ahli media, diperoleh saran untuk dilakukan perbaikan atau revisi, berikan pengantar atau intro sebelum masuk ke menu utama dan petunjuk penggunaan tombol.

Sesuai saran dari ahli media, bahan ajar yang dikembangkan diberikan intro. Halaman pertama intro berisi nama penyusun. Pada halaman kedua intro terdapat nama fakultas dan universitas penyusun. Sedangkan pada halaman ketiga intro terdapat judul bahan ajar, yaitu Bahan Ajar Interaktif Persamaan Garis Lurus. Dalam waktu kurang dari lima detik, halaman intro yang berisi judul bahan ajar akan otomatis berpindah ke halaman beranda. Saran kedua dari ahli media adalah petunjuk penggunaan tombol. Pada halaman beranda, ditambahkan tombol bantuan. Jika tombol bantuan diklik maka akan muncul halaman berisi fungsi-fungsi tombol yang ada, seperti tombol Beranda, Kompetensi, Bantuan, Suara, Lanjut, Kembali, dan Keluar.

Aspek tampilan secara keseluruhan diperoleh persentase rata-rata sebesar $82,50 \%$. Jika ditinjau dari aspek tampilan maka bahan ajar yang dikembangkan termasuk kategori sangat baik. Aspek suara secara keseluruhan diperoleh persentase rata-rata sebesar 75,00\%. Jika ditinjau dari aspek suara maka bahan ajar yang dikembangkan termasuk kategori baik. Aspek navigasi secara keseluruhan diperoleh persentase rata-rata sebesar $84,00 \%$. Jika ditinjau dari aspek navigasi maka bahan ajar yang dikembangkan termasuk kategori baik. Aspek interaktivitas secara keseluruhan diperoleh persentase rata-rata sebesar $90,00 \%$. Jika ditinjau dari aspek interaktivitas maka bahan ajar yang dikembangkan termasuk kategori baik. Persentase rata-rata secara keseluruhan dari aspek tampilan, suara, navigasi, maupun interaktivitas diperoleh nilai sebesar 82,90\%.

\section{Model Draft III}

Model draft III yang dihasilkan merupakan hasil dari uji coba perorangan dan hasil uji coba kelompok kecil. Perbaikan dari model draft II digunakan untuk uji coba perorangan. Uji coba perorangan dilaksanakan di SMP Negeri 30 Jakarta dengan responden sebanyak tiga orang. Diperoleh masukan untuk melakukan perbaikan atau revisi yaitu mengganti musik latar menjadi musik yang lebih menyenangkan dan tidak membosankan.

Dalam uji coba perorangan, aspek materi diperoleh persentase sebesar 85,60\%. Aspek bahasa diperoleh persentase sebesar $85,00 \%$. Persentase yang diperoleh aspek tampilan sebesar 
$86,70 \%$. Persentase yang diperoleh aspek navigasi sebesar $84,40 \%$. Persentase yang diperoleh dari aspek interaktivitas sebesar 90,00\%. Ditinjau dari kelima aspek tersebut, media yang dikembangkan sangat baik. Aspek suara memperoleh persentase sebesar 76,70. Jika ditinjau dari aspek suara maka bahan ajar yang dikembangkan termasuk kategori baik. Persentase rata-rata secara keseluruhan diperoleh nilai sebesar 84,70\%. Dalam uji coba lapangan kecil, aspek materi diperoleh persentase sebesar 90,30\%. Aspek bahasa diperoleh persentase sebesar 89,00\%. Persentase yang diperoleh aspek tampilan sebesar $85,00 \%$. Persentase yang diperoleh aspek suara sebesar $85,00 \%$. Persentase yang diperoleh aspek navigasi sebesar 89,30\%. Persentase aspek interaktivitas yang diperoleh sebesar $91,00 \%$. Jika bahan ajar yang dikembangkan ditinjau secara keseluruhan, persentase rata-rata sebesar $88,30 \%$ yang berarti sangat baik.

\section{Model Final}

Hasil revisi uji coba perorangan dan uji coba lapangan kecil kemudian diujicobakan di skala yang lebih besar, yaitu uji coba lapangan besar yang dilaksanakan di SMP Negeri 30 Jakarta dengan responden sebanyak 56 siswa. Pada tahap uji lapangan besar tidak ada perubahan pada model draft III. Siswa memberikan masukan untuk mengganti ukuran huruf menjadi lebih besar. Saran tersebut sangat baik untuk dilakukan tetapi jika perbesaran ukuran huruf dilakukan maka tulisan yang ada akan memenuhi layar sehingga proporsi antara tulisan dan gambar tidak proporsional.

Persentase aspek materi sebesar 91,40\%. Persentase aspek bahasa sebesar 92,20\%. Persentase aspek tampilan sebesar 88,20\%. Persentase aspek suara sebesar $86,80 \%$. Persentase aspek navigasi sebesar 91,20\%. Persentase aspek interaktivitas sebesar 93,40\%. Jika bahan ajar ditinjau secara keseluruhan, persentase yang diperoleh sebesar 90,50\% yang berarti sangat baik. Jadi, dapat dikatakan bahwa bahan ajar yang dikembangkan sangat baik dan layak untuk siswa.

\section{B. Pembahasan}

Langkah awal yang dilakukan untuk mengembangkan bahan ajar interaktif berbasis pendekatan kontekstual pada materi persamaan garis lurus adalah membuat diagram alir yang merupakan kerangka bahan ajar. Setelah itu dibuat GBIM. Kemudian membuat jabaran materi yang dikaitkan dengan asas pendekatan kontekstual. Permasalahan yang ditampilkan dalam jabaran materi adalah soal yang berkaitan dengan kehidupan sehari-hari. Jabaran materi dikembangkan menjadi story board. Story board yang telah dibuat direalisasikan ke dalam aplikasi Adobe Flash Professional CS6. Berikut adalah tujuh asas kontekstual dalam bahan ajar yang dikembangkan.

1. Konstruktivisme (Constructivism)

Konstruktivisme adalah proses membangun atau menyusun pengetahuan baru dalam struktur kognitif siswa berdasarkan pengalaman. Siswa diminta mengamati sebuah konteks. Konteks yang digunakan untuk asas konstruktivisme pada bahan ajar ini adalah konteks tangga karena tangga merupakan objek yang sering dijumpai siswa dalam kehidupan sehari-hari yang berkaitan dengan konsep gradien. Selain itu, konteks tangga juga sering dirasakan siswa. Tangga yang curam membuat siswa cepat lelah. Berlaku pula sebaliknya, tangga yang landai tidak membuat siswa cepat lelah. Kecuraman dan kelandaian tangga berkaitan dengan nilai gradien dari tangga tersebut. Semakin besar nilai gradien suatu benda maka semakin besar pula tingkat kecuraman benda tersebut.

Sasaran yang akan dicapai pada konteks tangga adalah siswa dapat memahami bahwa nilai gradien atau kemiringan suatu benda berbeda-beda, sesuai dengan panjang alas dan tinggi benda tersebut. Konsep tersebut akan dicapai setelah siswa mengamati ketiga tangga tersebut dan diberikan beberapa pertanyaan.

2. Inkuiri (Inquiry)

Inkuiri merupakan proses pembelajaran yang didasarkan pada pencarian dan penemuan melalui proses berpikir sistematis. Contoh inkuiri dalam bahan ajar ini terdapat pada sub materi 2 yaitu tentang menemukan konsep gradien garis sejajar melalui proses berpikir sistematis. Tujuan penerapan inkuiri pada konsep tersebut adalah siswa memahami konsep "Jika garis-garis memiliki gradien yang sama maka pasti garis-garis tersebut saling sejajar." bukan dari hasil mengingat, tetapi dari hasil menemukan sendiri. 


\section{Bertanya (Questioning)}

Dalam asas bertanya, guru tidak menyampaikan informasi begitu saja, akan tetapi memancing agar siswa dapat menemukan sendiri. Setelah diminta untuk menghubungkan titik-titik pada koordinat Cartesius seperti pada gamber tersebut, karakter profesor bertanya kepada siswa, "Setelah titik-titik tersebut kamu hubungkan, apa yang kamu peroleh?". Pertanyaan tersebut bertujuan agar pengetahuan mengenai persamaan garis lurus tidak diberikan begitu saja, akan tetapi diperoleh dari proses berpikir siswa melalui pertanyaan yang diberikan.

4. Masyarakat Belajar (Learning Community)

Konsep masyarakat belajar dalam pendekatan kontekstual menyarankan agar hasil pembelajaran diperoleh melalui kerja sama dengan orang lain. Penerapan asas masyarakat belajar dalam bahan ajar ini adalah diskusi antar teman. Dalam sub materi 1 siswa diminta untuk menempatkan titik-titik pada koordinat Cartesius yang disediakan, kemudian diminta untuk menghubungkan titik-titik tersebut. Setelah itu siswa diberi pertanyaan oleh karakter profesor, "Setelah titik-titik tersebut kamu hubungkan, apa yang kamu peroleh?", dilanjutkan dengan perintah, "Diskusikan dengan teman sebangkumu!". Perintah tersebut diberikan agar terjadi kerja sama antara siswa yang satu dengan yang lain.

\section{Pemodelan ( Modeling)}

Pemodelan merupakan proses pembelajaran dengan memperagakan sesuatu sebagai contoh yang dapat ditiru. Misalnya, terdapat karakter animasi pada bahan ajar yang memberikan contoh bagaimana cara menyelesaikan permasalahan yang berkaitan dengan persamaan garis lurus. Contoh penerapan pemodelan pada bahan ajar ini yaitu mengenai cara menentukan persamaan garis jika gradien dan satu titik diketahui.

6. Refleksi (Reflection)

Refleksi adalah proses pengendapan pengalaman yang telah dipelajari yang dilakukan dengan cara mengurutkan kembali peristiwa pembelajaran untuk mengingat kembali apa yang sudah dipelajarinya. Contoh kalimat refleksi pada sub materi gradien adalah "Setelah mempelajari Gradien, coba kamu ingat, adakah bagian yang belum kamu pahami? Jika ada, coba pelajari kembali atau diskusikan dengan teman sebangkumu!". Kemudian dilanjutkan dengan, "Buatlah rangkuman tentang apa yang telah kamu pahami dan catatlah hal-hal yang sulit kamu pahami!" agar hal-hal yang telah dipahami dapat tersimpan dengan baik dalam ingatan siswa. Pertanyaan selanjutnya adalah mengenai arti gradien, cara mencari gradien, gradien garis sejajar, dan gradien garis tegak lurus. Siswa menjelaskan pertanyaan tersebut dengan bahasa siswa sendiri.

7. Penilaian nyata (Authentic Assessment)

Penilaian nyata adalah proses yang dilakukan guru untuk mengumpulkan informasi tentang perkembangan belajar yang dilakukan siswa. Penilaian ini dilakukan secara terus menerus selama kegiatan berlangsung. Peran guru dalam penilaian nyata sangat diperlukan agar asas penilaian nyata dalam bahan ajar ini terpenuhi. Bahan ajar ini hanya menampilkan pertanyaan-pertanyaan dalam setiap sub materi. untuk memfasilitasi guru melakukan penilaian nyata. Pada bagian akhir bahan ajar terdapat penilaian berupa soal evaluasi.

Bahan ajar interaktif yang dikembangkan memiliki kelebihan dan kekurangan. Kelebihan yang dimiliki oleh bahan ajar yang dikembangkan yaitu bersifat interaktif sehingga membuat siswa termotivasi untuk belajar. Tampilan bahan ajar yang dikembangkan sangat menarik didukung dengan musik latar yang cukup bagus. Isi materi yang dipaparkan dalam bahan ajar yang dikembangkan sudah dengan tujuan pembelajaran. Materi dalam bahan ajar yang dikembangkan berkaitan dengan konteks kehidupan sehari-hari sehingga pembelajaran menjadi lebih bermakna. Kekurangan yang ada pada bahan ajar yang dikembangkan adalah bahan ajar tidak selalu kompatibel dengan komputer yang digunakan. Bahan ajar yang dikembangkan juga memerlukan perangkat komputer yang yang memadai seperti CD-Rom. Selain itu materi pada bahan ajar yang dikembangkan terbatas yaitu hanya materi persamaan garis lurus.

\section{Kesimpulan, Implikasi, dan Saran}

A. Kesimpulan

1. Penelitian pengembangan yang dilakukan telah menghasilkan bahan ajar berupa bahan ajar interaktif berbasis pendekatan kontekstual pada materi persamaan garis lurus untuk kelas VIII SMP. Langkah awal yang dilakukan untuk mengembangkan bahan ajar interaktif pada materi 
persamaan garis lurus berbasis pendekatan kontekstual adalah membuat diagram alir tampilan bahan ajar interaktif sebagai kerangka bahan ajar. Setelah itu dibuat GBIM. Kemudian disusun jabaran materi yang dikaitkan dengan tujuh asas pendekatan kontekstual. Permasalahan yang ditampilkan dalam jabaran materi adalah soal yang berkaitan dengan kehidupan sehari-hari. Jabaran materi yang telah dibuat dikembangkan menjadi story board. Story board yang telah dibuat direalisasikan ke dalam aplikasi Adobe Flash Professional CS6.

2. Persentase rata-rata keseluruhan angket pada tahap uji ahli materi dan bahasa sebesar $89,40 \%$, yaitu sangat baik. Berdasarkan ahli media diperoleh presentase rata-rata keseluruhan sebesar $82,90 \%$ yaitu sangat baik. Persentase uji coba perorangan sebesar $84,70 \%$, yaitu sangat baik. Persentase uji coba lapangan kecil sebesar 88,30\%, yaitu sangat baik. Persentase uji coba lapangan besar sebesar 90,50\% yaitu sangat baik. Berdasarkan persentase yang diperoleh, dapat dikatakan bahwa bahan ajar yang dikembangkan sudah layak digunakan kepada siswa untuk pembelajaran persamaan garis lurus.

\section{B. Implikasi}

Hasil penelitian pengembangan bahan ajar interaktif berbasis pendekatan kontekstual pada materi persamaan garis lurus merupakan produk yang dapat digunakan sebagai alternatif pilihan bahan ajar dalam pembelajaran di kelas. Produk ini diharapkan dapat menciptakan pembelajaran yang lebih menarik dan bermakna.

\section{Saran}

1. Bahan ajar interaktif ini lebih baik digunakan di dalam pembelajaran di kelas oleh guru agar seluruh asas kontekstual yang ada dapat terpenuhi. Selain itu agar guru dapat mengamati perkembangan cara berpikir siswa.

2. Perlu adanya kelanjutan pengembangan bahan ajar interaktif untuk siswa SMP sebagai bahan ajar untuk materi, tingkatan, dan bidang studi lain.

3. Perlu dilakukan penelitian lanjutan untuk mengetahui pengaruh media pembelajaran interaktif dengan pendekatan kontekstual yang telah dihasilkan dalam meningkatan hasil belajar matematika siswa pada materi persamaan garis lurus.

\section{DAFTAR PUSTAKA}

Agus, Nuniek Avianti. 2008. Mudah Belajar Matematika. Jakarta: Pusat Perbukuan Departemen Pendidikan Nasional.

BSNP. 2006. Standar Isi; Untuk Satuan Pendidikan Dasar dan Menengah. Jakarta: Badan Standar Nasional Pendidikan (BSNP).

Hanafiah, Nanang, dkk. 2009. Konsep Strategi Pembelajaran. Bandung: PT Refika Aditama.

Idris, Husni. 2008. "Pengembangan Multimedia Pembelajaran Berbantuan Komputer." Jurnal Iqra' Vol. 5. Manado: STAIN Manado.

Maemanah, Sri. 2007. Pelajaran Matematika; Untuk SMP/MTs Kelas VIII. Depok: Arya Duta.

Majid, Abdul. 2005 Perencanaan Pembelajaran; Mengembangkan Standar Kompetensi Guru. Bandung: PT Remaja Rosdakarya.

Maryani, Sri. 2009. "Pengembangan Bahan Ajar Berbasis Multimedia Interaktif Mata Kuliah Komputansi Akuntansi." Tesis. Universitas Gunadarma.

Prastowo, Andi. 2011. Panduan Kreatif Membuat Bahan Ajar Inovatif. Jogjakarta: DIVA Press.

Pribadi, Benny A. 2009 Model Desain Sistem Pembelajaran. Jakarta: Dian Rakyat.

Yoppy dkk. 2011. "Efektivitas Contextual Teaching and Learning (CTL) Ditinjau dari Motivasi Belajar Siswa pada Pembelajaran Matematika." Prosiding Seminar Nasional Matematika dan Pendidikan Matematika Universitas Muhammadiyah Surakarta. Surakarta: Muhammadiyah University Press.

Putra, Nusa. 2011. Research \& Development. Jakarta: PT RajaGrafindo Persada.

Riduwan. 2007. Belajar Mudah Penelitian untuk Guru - Karyawan dan Peneliti Pemula. Bandung: Alfabeta.

Sanjaya, Wina. 2010. Kurikulum dan Pembelajaran. Jakarta: Kencana. 
—. 2010. Strategi Pembelajaran; Berorientasi Standar Proses Pendidikan. Jakarta: Kencana.

Eveline dkk. 2010. Buku Ajar Teori Belajar dan Pembelajaran. Jakarta: Universitas Negeri Jakarta.

Sugiyono. 2009. Metode Penelitian Kuantitatif Kualitatif dan R\&D. Bandung: Alfabeta.

Tata. 2010. "Penggunaan Media Pembelajaran CD Interaktif Berbasis Komputer dalam Meningkatkan Pemahaman Konsep Matematika." Skripsi. Universitas Pendidikan Indonesia: Tidak diterbitkan.

Tim Puslitjaknov. 2008. Metode Penelitian dan Pengembangan. Jakarta: Pusat Penelitian Kebijakan dan Inovasi Pendidikan Badan Penelitian dan Pengembangan Departemen Pendidikan Nasional. 